\title{
Prolactin stimulates the proliferation of normal female cholangiocytes by differential regulation of $\mathrm{Ca}^{2+}$-dependent PKC isoforms
}

\author{
Silvia Taffetani ${ }^{1}$, Shannon Glaser ${ }^{2,3}$, Heather Francis ${ }^{3}$, Sharon DeMorrow ${ }^{2,3}$, \\ Yoshiyuki Ueno ${ }^{4}$, Domenico Alvaro ${ }^{5}$, Luca Marucci ${ }^{1}$, Marco Marzioni ${ }^{1}$, \\ Giammarco Fava1, Julie Venter ${ }^{2}$, Shelley Vaculin'6, Bradley Vaculin², Ian Pak- \\ Yan Lam7, Vien Hoi-Yi Lee ${ }^{7}$, Eugenio Gaudio ${ }^{8}$, Guido Carpino ${ }^{8}$, \\ Antonio Benedetti ${ }^{1}$ and Gianfranco Alpini*2,6,9
}

Address: ${ }^{1}$ Department of Gastroenterology, Università Politecnica delle Marche, Nuovo Polo Didattico, III piano, Via Tronto 10 Ancona, 60020 , Italy, ${ }^{2}$ Department of Medicine, Scott \& White Hospital and Texas A\&M University System Health Science Center, College of Medicine, MRB, 702 SW H.K. Dodgen Loop, Temple, TX, 76504, USA, ${ }^{3}$ Division of Research and Education, Scott \& White Hospital and Texas A\&M University System Health Science Center, College of Medicine, MRB, 702 SW H.K. Dodgen Loop, Temple, TX, 76504, USA, ${ }^{4}$ Division of Gastroenterology, Tohoku University School of Medicine, 1-1 Seiryo, Aobaku, Sendai 980-8574, Japan, ${ }^{5}$ Division of Gastroenterology, University of Rome, "La Sapienza", via Roberto Rossellini 51, 00137 Rome, Italy, ${ }^{6}$ Division of Research, Central Texas Veterans Health Care System, MRB, 702 SW H.K. Dodgen Loop, Temple, TX, 76504, USA, ${ }^{7}$ School of Biological Sciences, The University of Hong Kong, Pokfulam Road, Hong Kong, China, ${ }^{8}$ Department of Human Anatomy, University of Rome, "La Sapienza", Via Alfonso Borelli 50, 00161, Rome, Italy and ${ }^{9}$ Department of Systems Biology and Translational Medicine, Texas A\&M University System Health Science Center, College of Medicine, MRB, 702 SW H.K. Dodgen Loop, Temple, TX, 76504, USA

Email: Silvia Taffetani - taffetanisilvia@yahoo.it; Shannon Glaser - sglaser@tamu.edu; Heather Francis - hfrancis@tamu.edu; Sharon DeMorrow - demorrow@medicine.tamhsc.edu; Yoshiyuki Ueno - yueno@mail.tains.tohoku.ac.jp;

Domenico Alvaro - domenico.alvaro@uniroma1.it; Luca Marucci - psterpetti@yahoo.com; Marco Marzioni - m.marzioni@univpm.it; Giammarco Fava - giammarcofava@hotmail.com; Julie Venter - Jventer@tamu.edu; Shelley Vaculin - sevaculin@medicine.tamhsc.edu; Bradley Vaculin - bradley-thomas@tamu.edu; Ian Pak-Yan Lam - ianlam@hkusua.hku.hk; Vien Hoi-Yi Lee - h0230446@hkusua.hku.hk; Eugenio Gaudio - paolo.onori@uniroma1.it; Guido Carpino - antonio.franchitto@uniroma1.it; Antonio Benedetti - a.benedetti@aoumbertoprimo.marche.it; Gianfranco Alpini* - galpini@tamu.edu

* Corresponding author

Published: 19 July 2007

BMC Physiology 2007, 7:6 doi:10.1 186/1472-6793-7-6
Received: 5 February 2007

Accepted: 19 July 2007

This article is available from: http://www.biomedcentral.com/1472-6793/7/6

(C) 2007 Taffetani et al; licensee BioMed Central Ltd.

This is an Open Access article distributed under the terms of the Creative Commons Attribution License (http://creativecommons.org/licenses/by/2.0), which permits unrestricted use, distribution, and reproduction in any medium, provided the original work is properly cited.

\begin{abstract}
Background: Prolactin promotes proliferation of several cells. Prolactin receptor exists as two isoforms: long and short, which activate different transduction pathways including the $\mathrm{Ca}^{2+}$-dependent PKC-signaling. No information exists on the role of prolactin in the regulation of the growth of female cholangiocytes. The rationale for using cholangiocytes from female rats is based on the fact that women are preferentially affected by specific cholangiopathies including primary biliary cirrhosis. We propose to evaluate the role and mechanisms of action by which prolactin regulates the growth of female cholangiocytes.

Results: Normal cholangiocytes express both isoforms (long and short) of prolactin receptors, whose expression increased following BDL. The administration of prolactin to normal female rats increased cholangiocyte proliferation. In purified normal female cholangiocytes, prolactin stimulated cholangiocyte proliferation, which was associated with increased $\left[\mathrm{Ca}^{2+}\right]_{i}$ levels and PKC $\beta-I$ phosphorylation but decreased PKC $\alpha$ phosphorylation. Administration of an antiprolactin antibody to BDL female rats decreased cholangiocyte proliferation. Normal female cholangiocytes express and
\end{abstract}


secrete prolactin, which was increased in BDL rats. The data show that prolactin stimulates normal cholangiocyte growth by an autocrine mechanism involving phosphorylation of PKC $\beta-I$ and dephosphorylation of PKC $\alpha$.

Conclusion: We suggest that in female rats: (i) prolactin has a trophic effect on the growth of normal cholangiocytes by phosphorylation of PKC $\beta$-I and dephosphorylation of PKC $\alpha$; and (iii) cholangiocytes express and secrete prolactin, which by an autocrine mechanism participate in regulation of cholangiocyte proliferation. Prolactin may be an important therapeutic approach for the management of cholangiopathies affecting female patients.

\section{Background}

Cholangiocytes have a low replicative activity in the normal state [1-3], but they proliferate or undergo apoptosis in cholangiopathies [3-6], progressive liver disorders characterized by an abnormal balance between cholangiocyte proliferation and death, leading to vanishing of intrahepatic bile ducts $[3,4]$. It has been hypothesized that sex hormones play a role in the pathogenesis of some cholangiopathies $[4,7,8]$. In particular, the most common of them, primary biliary cirrhosis $(\mathrm{PBC})$, is more common in women, and its clinical outbreak is typically after menopause $[4,9]$. The low expression of estrogen receptor alpha in PBC and their disappearance in the advanced histological stages of this disease suggests that an estrogenic deficiency could favor the evolution of PBC toward ductopenia [7]. Furthermore, a study demonstrated that: (i) ovariectomy to BDL female rats induced a decrease in intrahepatic ductal mass; and (ii) administration of $17-\beta$ estradiol during BDL to ovariectomized rats prevented the decrease in the number of bile ducts [10].

Prolactin is a pituitary hormone and a pleiotropic cytokine that promotes cellular proliferation, differentiation and survival in a number of cells [11]. Two different isoforms of the prolactin receptor exist: they are both encoded by a single gene, by which the two isoforms (a short and a long form) are obtained by alternative splicing [12]. The long and short forms are both membrane bound receptors with an identical binding site for prolactin, but differ in the length of their cytoplasmic tail [12]. Prolactin binding to the long or short form of prolactin receptors activates different signaling pathways including mitogenactivated protein kinase (MAPK) [13], JAK/STAT [14], and $\mathrm{Ca}^{2+} / \mathrm{PKC}$ [13]. While long prolactin receptors activate several signaling pathways including JAK/STAT [15], the short isoform of prolactin receptor activates various kinases and interacts with 17-hydroxy-steroid dehydrogenase pathways $[16,17]$. The long form of the prolactin receptor mediates activation of the $\mathrm{Ca}^{2+}$-dependent PKC signaling in a number of cells $[18,19]$.

Although studies have shown differences in the expression of prolactin receptors between hepatocytes and cholangiocytes of normal and cholestatic livers [20-23], no information exists on the role of prolactin on the regulation of cholangiocyte growth. The rationale for using cholangiocytes from female rats is based on the fact that women are preferentially affected by specific cholestatic liver diseases including PBC [9]. We addressed these questions: (i) Do normal and BDL female and male cholangiocytes express prolactin receptors? (ii) Does in vivo administration of prolactin to normal female and male rats increase cholangiocyte proliferation? (iii) Are prolactin effects on normal cholangiocyte proliferation of female rats associated with increased intracellular $\mathrm{Ca}^{2+}$ $\left(\left[\mathrm{Ca}^{2+}\right]_{\mathrm{i}}\right)$ levels and differential phosphorylation of $\mathrm{Ca}^{2+}$ dependent PKC isoforms $(\alpha, \beta-\mathrm{I}, \beta$-II and $\gamma$, which are important in the regulation of biliary functions) [24-29]? (iv) Does the in vivo administration of an anti-prolactin antibody to BDL female and male rats inhibit cholangiocyte hyperplasia? and (v) Do female cholangiocytes express the message and protein for prolactin and secrete prolactin?

\section{Results \\ Cholangiocytes express prolactin receptors}

Immunohistochemistry in liver sections from normal and BDL female and male rats shows that cholangiocytes express prolactin receptors (Figure 1, see arrows). By immunofluorescence, immunoreactivity for prolactin receptor is co-localized with the expression of cytokeratin19 (CK-19, a marker of cholangiocytes) [2] (Figure 2); in the merged photograph there is co-localization of prolactin receptor and CK-19 (Figure 2). No immunohistochemical reaction was observed when a consecutive liver section of the same field was incubated with non-immune serum (Figure 1). Parallel to other studies [23], prolactin receptors are also expressed by hepatocytes from normal and BDL female and male rats (Figures 1 and 2).

By RT-PCR, normal and BDL female cholangiocytes expressed the expected molecular weight band for the message for the short (582 bp) and long (781 bp) form of prolactin receptor, and for glyceraldehyde-3-phosphate dehydrogenase (GAPDH, the housekeeping gene) (294 bp) (not shown). Sequence analysis of the RT-PCR fragments shows that both the rat short and long prolactin receptors are $98 \%$ homologous to the short (NCBI Genbank accession No. NM 012630) [23] and long rat prolactin receptor mRNAs (NCBI Genbank accession No. NM 001034111) [23]. By real time PCR, normal female cholangiocytes express both the short and long form of 

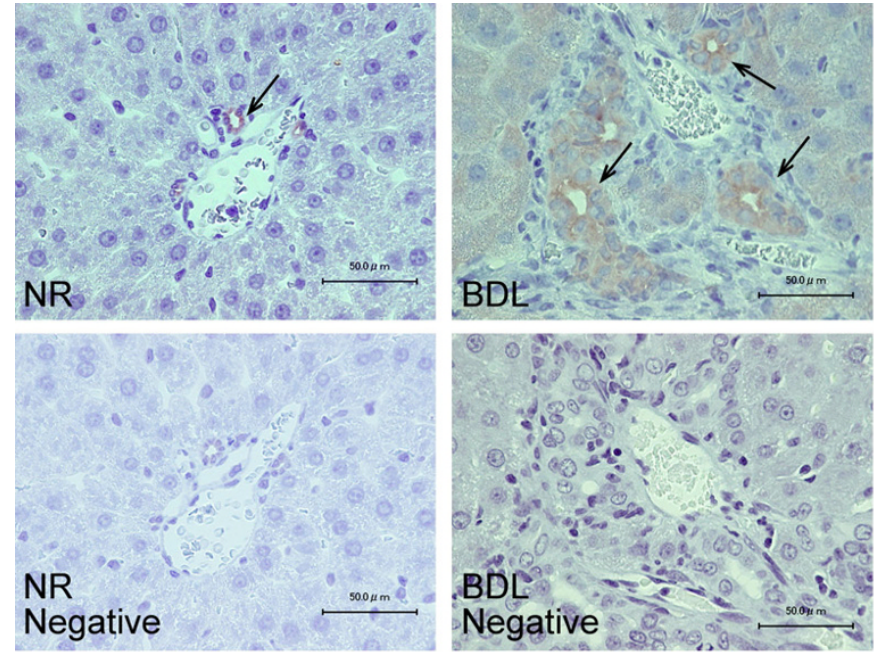

Female Rats
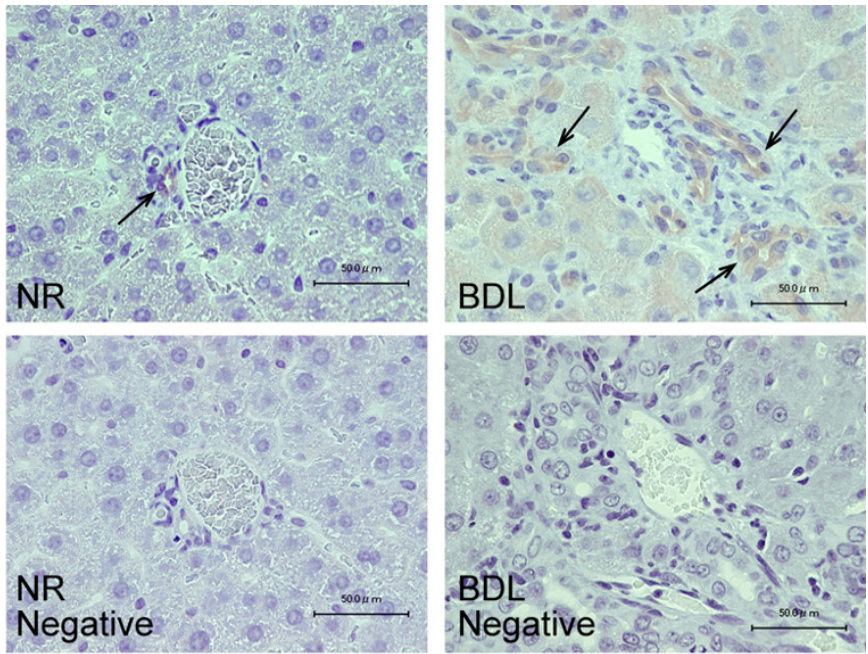

Male Rats

Figure I

The localization of prolactin receptor in the liver was evaluated by immunohistochemistry (scale bar $=50 \mu \mathrm{m}$ ) in liver sections from normal and BDL female and male rats. Bile ducts from normal and BDL female and male rats express these receptors (arrows). No immunohistochemical reaction was observed when a consecutive liver section of the same field was incubated with non-immune serum. Hepatocytes from normal and BDL female and male rats express the prolactin receptor.

prolactin receptor mRNA (expressed as a ratio to GAPDH mRNA) (Figure 3); following BDL, the expression of the short and long form of prolactin receptor mRNA significantly increased in purified female cholangiocytes (Figure 3).

\section{Effect of in vivo administration of prolactin to normal rats on serum prolactin levels, portal inflammation, necrosis and cholangiocyte apoptosis and proliferation}

Chronic in vivo administration of prolactin to normal female rats increased prolactin serum levels compared to normal rats treated with $\mathrm{NaCl}$ for 1 week (Table 1 ). H\&E staining of paraffin-embedded liver sections demonstrated that there were no significant differences in the degree of portal inflammation, necrosis, apoptosis and lobular damage between NaCl- and prolactin-treated normal female rats (Table 1). Administration of prolactin to normal female rats increased the number of proliferating cellular nuclear antigen (PCNA)- and CK-19-positive cholangiocytes compared with normal rats treated with $\mathrm{NaCl}$ (Figure 4). Prolonged administration of prolactin to normal male rats did not change intrahepatic ductal mass (evaluated by $\gamma$-GT histochemistry) [30] compared to normal male rats treated with $\mathrm{NaCl}[1.0 \pm 0.2 \%$ volume (normal + prolactin) vs. $1.0 \pm 0.2 \%$ volume $($ normal $+\mathrm{NaCl})$; not significantly different].

\section{Effect of prolactin on $\left[\mathrm{Ca}^{2+}\right]_{i}$ levels and phosphorylation of $\mathrm{Ca}^{2+}$-dependent PKC isoforms in normal female cholangiocytes}

Prolactin induced a sustained increase in $\left[\mathrm{Ca}^{2+}\right]_{\mathrm{i}}$ levels in normal female cholangiocytes compared with cholangiocytes treated with $0.2 \%$ BSA (Figure 5, top panel). A calcium tracing, which is the average of three independent measurements, is shown in Figure 5 (lower panel). As the tracing shows there is no change in fluorescence during the basal measurement period that demonstrates that the cells do not leak as influx of extracellular calcium would alter fluorescence (Figure 5, lower panel). Cholangiocyte responsiveness to the $\mathrm{Ca}^{2+}$ ionophore, ionomycin [31], is shown in Figure 5 (lower panel).

When purified female cholangiocytes were treated with prolactin, there was an increase in the phosphorylation of PKC $\beta$-I and a decrease in PKC $\alpha$ phosphorylation (Figure $6)$; no significant changes in the phosphorylation of PKC $\beta$-II and PKC $\gamma$ were observed in normal female cholangiocytes treated with prolactin (Figure 6).

\section{Effect of in vivo administration of anti-prolactin antibody on cholangiocyte proliferation of BDL rats \\ Cholangiocytes express prolactin}

The administration of anti-prolactin antibody to BDL female rats decreased prolactin serum levels and ameliorates portal inflammation, necrosis and lobular damage compared to BDL rats treated with non-immune serum 


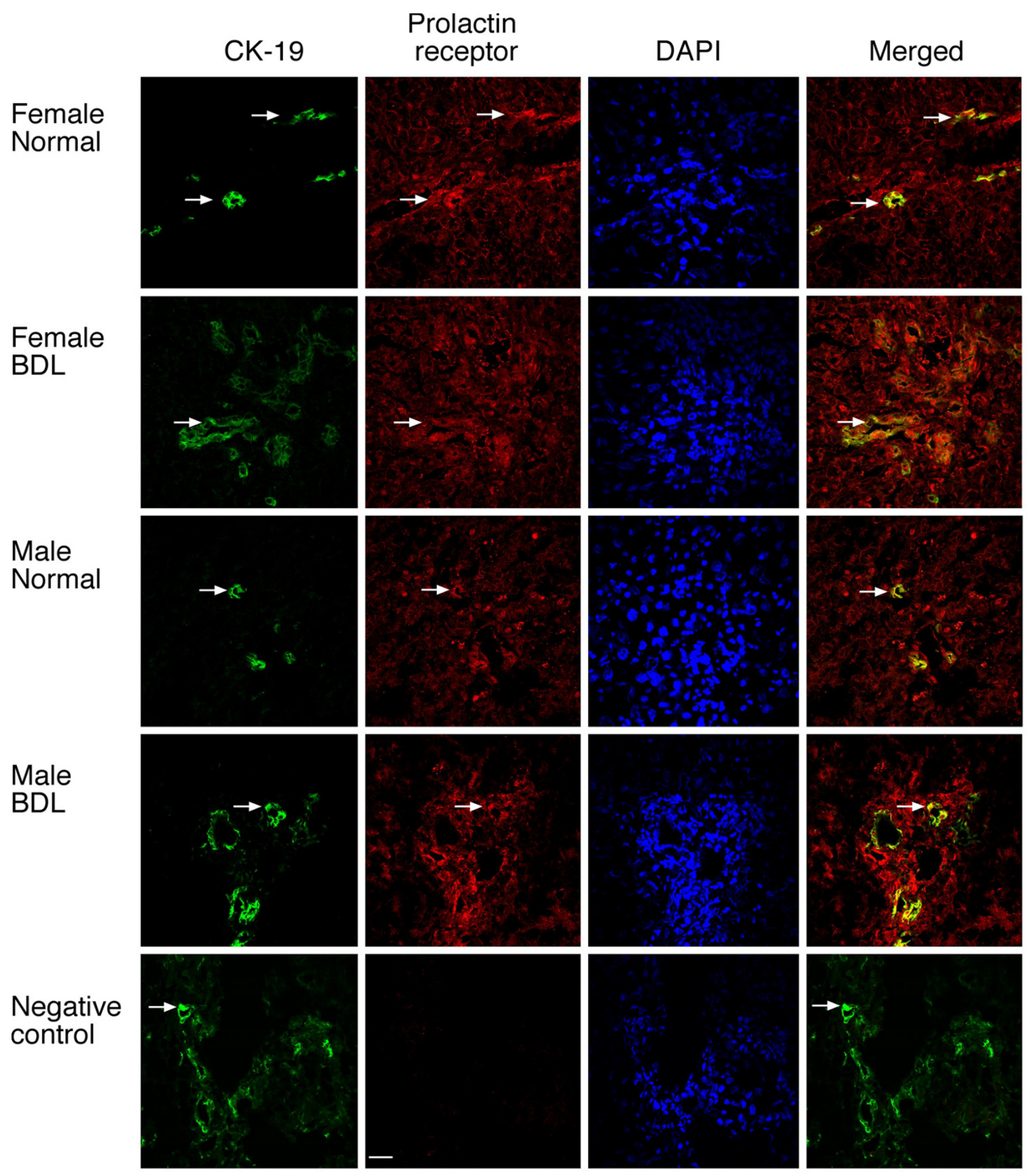

\section{Figure 2}

The localization of prolactin receptor in the liver was evaluated by immunofluorescence (scale bar $=20 \mu \mathrm{m}$ ) in liver sections from normal and BDL female and male rats. By immunofluorescence, prolactin receptor immunoreactivity (red) was co-localized with CK-19 immunoreactivity (green; indicated by arrows) demonstrating cholangiocyte expression; sections were counterstained with DAPI; in the merged photograph we show co-localization of prolactin receptor and CK-19. Hepatocytes from normal and BDL female and male rats express the prolactin receptor. 

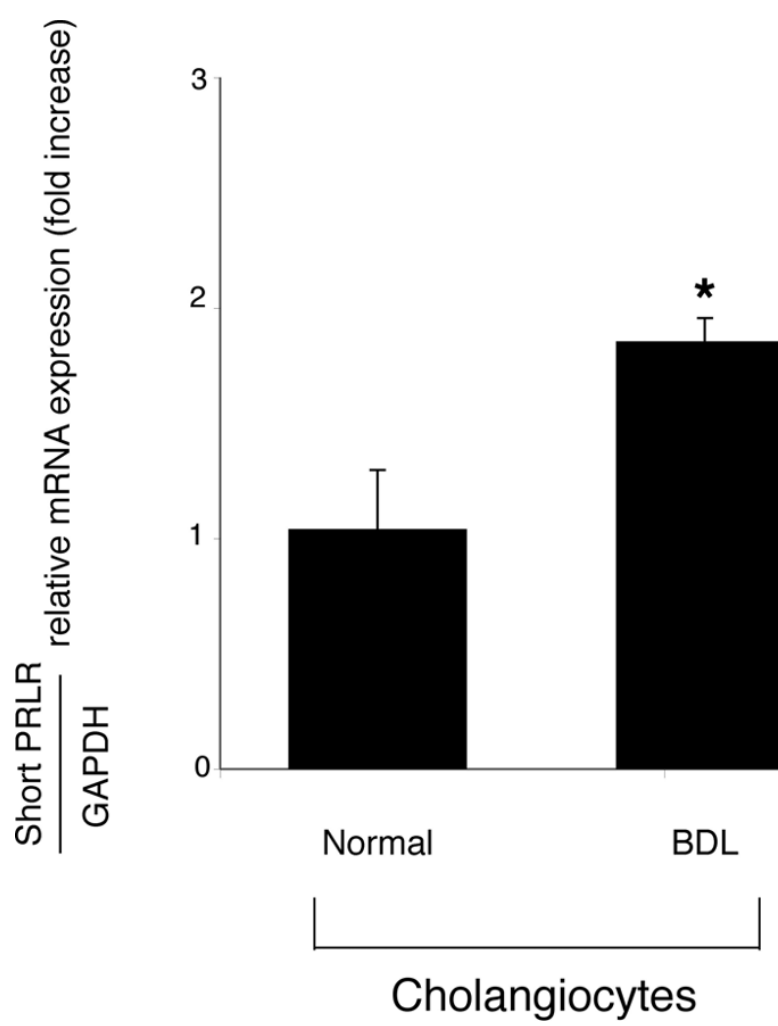
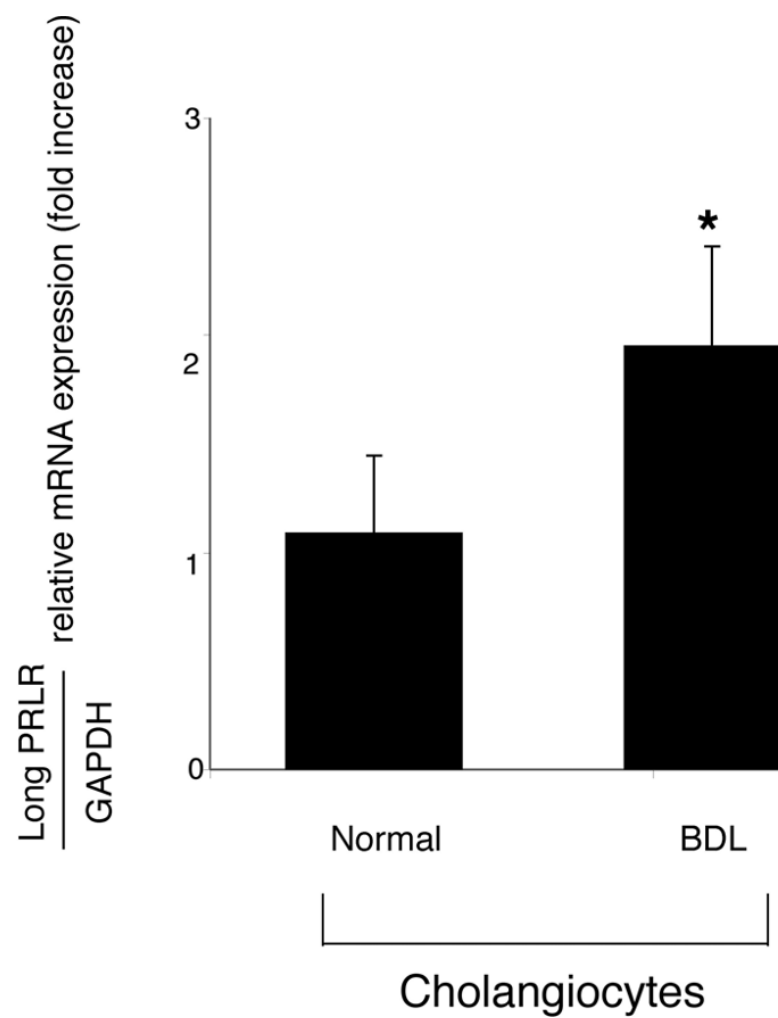

Figure 3

Real time PCR for the message for the short and long form of prolactin receptor in total cholangiocyte RNA (0.75 $\mu$ g) from normal and BDL female rats. Normal female cholangiocytes express both the short and long form of prolactin receptor mRNA (expressed as ratio to GAPDH mRNA); following BDL, the expression of both the short and long form of prolactin receptor mRNA (expressed as ratio to GAPDH mRNA) significantly increased in purified cholangiocytes. Data are mean \pm SEM of 3 experiments. ${ }^{*} p<0.05$ vs. relative expression of short and long prolactin receptor mRNA of normal cholangiocytes. NR = normal rat; PRLR = prolactin receptor.

for 1 week (Table 1 ). Administration of anti-prolactin antibody to BDL female rats decreased the number of PCNA- and CK-19-positive positive cholangiocytes compared to liver sections from BDL rats treated with nonimmune serum (Figure 7). Prolonged administration of anti-prolactin antibody to BDL male rats did not change intrahepatic ductal mass (evaluated by $\gamma$-GT histochemistry) [30] compared to BDL male rats treated non-immune serum $[4.5 \pm 1.0 \%$ volume $(\mathrm{BDL}+$ anti-prolactin anti-

Table I: Evaluation of prolactin serum levels, inflammation, necrosis, lobular damage and apoptosis in liver sections after in vivo administration of: (i) $\mathrm{NaCl}$ or prolactin to normal rats for I week; or (ii) anti-prolactin antibody or non-immune serum to BDL (immediately following BDL) rats for I week.

\begin{tabular}{|c|c|c|c|c|}
\hline Treatment & $\begin{array}{c}\text { Normal rats }+\mathrm{NaCl} \text { for I } \\
\text { week }\end{array}$ & $\begin{array}{c}\text { Normal rats + PRL for I } \\
\text { week }\end{array}$ & $\begin{array}{l}\text { BDL rats + non-immune } \\
\text { serum for I week }\end{array}$ & $\begin{array}{l}\text { BDL rats + anti-PRL } \\
\text { antibody for I week }\end{array}$ \\
\hline Prolactin serum levels $(\mathrm{ng} / \mathrm{ml})$ & $6.6 \pm 0.16$ & $98.4 \pm 1.5^{*}$ & $63.4 \pm 1.0$ & $14.0 \pm 0.2^{*}$ \\
\hline Inflammation & $0 \pm 0$ & $0.4 \pm 0.2^{\mathrm{ns}}$ & $1.6 \pm 0.2$ & $0.8 \pm 0.2^{*}$ \\
\hline Necrosis & $0 \pm 0$ & $0.42 \pm 0.2^{\mathrm{ns}}$ & $1.0 \pm 0.0$ & $0.6 \pm 0.2^{*}$ \\
\hline Lobular damage & $0.06 \pm 0.06$ & $0.26 \pm 0.1 \mathrm{I}^{\mathrm{ns}}$ & $1.8 \pm 0.14$ & $0.9 \pm 0.06^{*}$ \\
\hline Cholangiocyte Apoptosis & $0 \pm 0$ & $0.2 \pm 0.2^{\mathrm{ns}}$ & $0.6 \pm 0.2$ & $0.8 \pm 0.2^{\mathrm{ns}}$ \\
\hline
\end{tabular}

Inflammation, necrosis, lobular damage and apoptosis were evaluated in paraffin embedded liver sections ( $5 \mu \mathrm{m})$ stained with hematoxylin and eosin. In vivo administration of prolactin to normal rats for I week increased prolactin serum levels but did not alter liver inflammation, necrosis, lobular damage or apoptosis compared to NaCl-treated normal female rats. The administration of anti-prolactin antibody to BDL female rats decreased prolactin serum levels and ameliorated portal inflammation, necrosis and lobular damage compared to BDL rats treated with non-immune serum for I week. Data on prolactin serum levels are mean \pm SEM of 3 samples from 3 different rats. Data (mean \pm SEM) related to the measurement of inflammation, necrosis, lobular damage and cholangiocyte apoptosis are obtained from the analysis of 3 slides per portal tract. $*_{p}<0.05$ vs. its corresponding value from BDL rats treated with non-immune serum. 


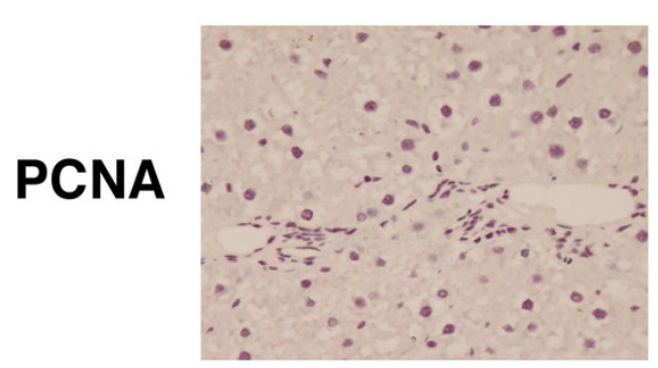

Normal rat $+\mathrm{NaCl} 1$ week

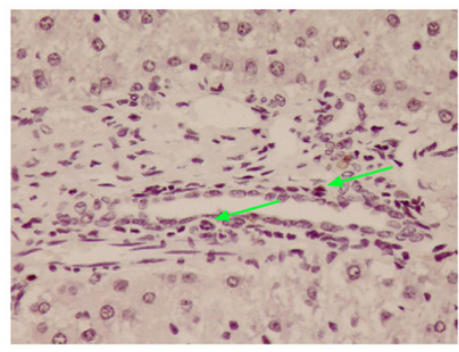

Normal rat + prolactin 1 week

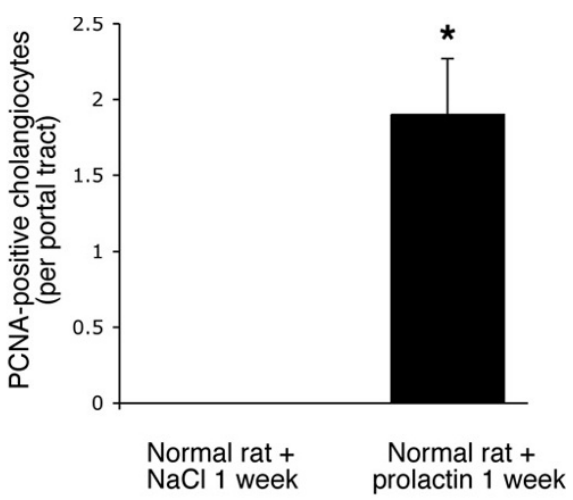

CK-19

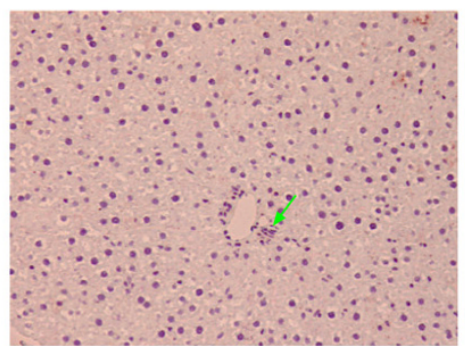

Normal rat $+\mathrm{NaCl} 1$ week

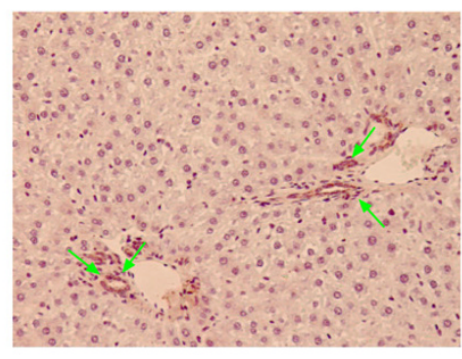

Normal rat + prolactin 1 week

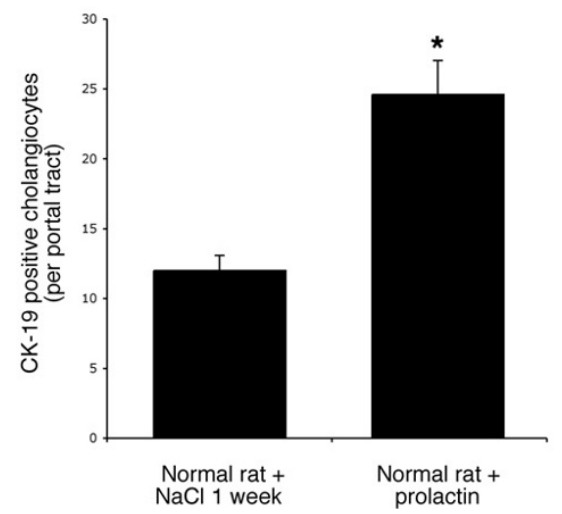

\section{Figure 4}

Measurement of the number of [top panel] PCNA- and [lower panel] CK-I9-positive cholangiocytes in liver sections $(5 \mu \mathrm{m}, 3$ slides analyzed per group) and [c] PCNA protein expression in purified female cholangiocytes from $\mathrm{NaCl}$ - or prolactin-treated rats. Administration of prolactin to normal female rats increased the number of PCNA-positive cholangiocytes (arrows) and CK-I9-positive cholangiocytes compared with normal rats treated with $\mathrm{NaCl}$. Orig. magn., $\times 20(\mathrm{PCNA})$ and $\times 10$ (CK-I9). Data are mean \pm SEM of 5 values obtained from the 3 slides evaluated per each group of animal. $* p<0.05$ vs. the corresponding value of $\mathrm{NaCl}$-treated rats.

body) vs. $3.7 \pm 0.8 \%$ volume $(\mathrm{BDL}+$ non-immune serum); not significantly different].

By immunohistochemistry in liver sections, bile ducts from normal and BDL female rats express the protein for prolactin (Figure 8, arrows). No staining was seen when a consecutive liver section of the same field was incubated with non-immune serum (Figure 8). By real time PCR, we have demonstrated that: (i) female normal cholangiocytes express prolactin mRNA at low levels (Figure 9); (ii) following BDL, prolactin mRNA markedly increased in female cholangiocytes (Figure 9); and (iii) primary cultures of normal and BDL female cholangiocytes secrete prolactin $[14.0 \pm 1.0 \mathrm{ng} / \mathrm{ml}$ (normal cholangiocytes); and $11.0 \pm 2.2 \mathrm{ng} / \mathrm{ml}$ (BDL cholangiocytes); $\mathrm{n}=7$ ).

\section{Discussion}

Our study demonstrates that prolactin regulates the growth of female cholangiocytes presumably by an autocrine mechanism. We first demonstrated in liver sections that cholangiocytes from normal and BDL female and male rats express prolactin receptors. By real time PCR: (i) normal female cholangiocytes expressed both the short and long form of prolactin receptor mRNA; and (ii) following BDL, the expression of the short and long form of prolactin receptors increased in female cholangiocytes. Our data on cholangiocyte prolactin receptor expression are slightly different to those of previous studies in albino mongrel rats [23] showing that: (i) normal isolated intrahepatic bile duct units (IBDU) predominantly express the message for the long form of the prolactin receptor, 

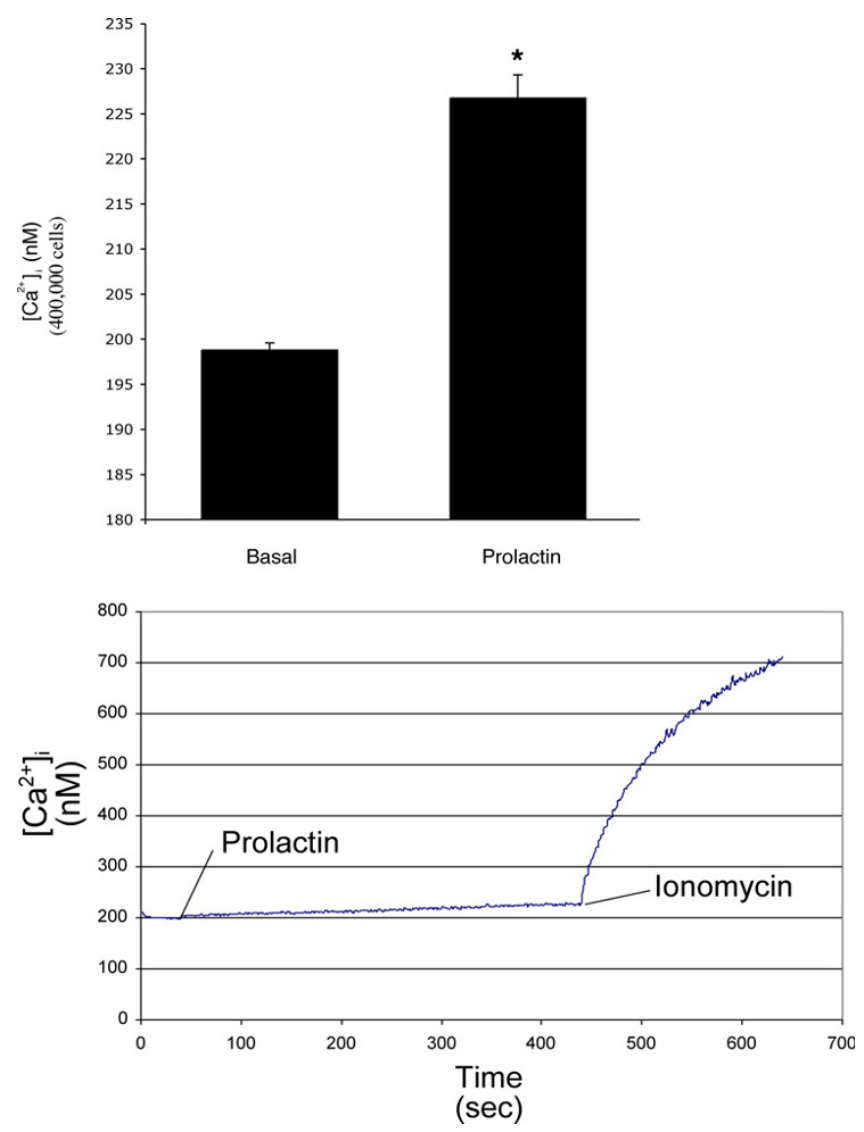

\section{Figure 5}

Determination of $\left[\mathrm{Ca}^{2+}\right]_{i}$ levels in female normal rat cholangiocytes treated with $0.2 \%$ BSA or $100 \mathrm{nM}$ prolactin. Prolactin induced a sustained increase in $\left[\mathrm{Ca}^{2+}\right]_{i}$ levels compared with cholangiocytes treated with $0.2 \%$ BSA [top panel]. Data are mean \pm SEM of 4 experiments. ${ }^{*} p<0.05$ vs. the corresponding basal values. [lower panel] A calcium tracing, which is the average of three independent measurements, is shown in shown. As the tracing shows there is no change in fluorescence during the basal measurement period that demonstrates that the cells do not leak as influx of extracellular calcium would alter fluorescence. Cholangiocyte responsiveness to the $\mathrm{Ca}^{2+}$ ionophore, ionomycin, is shown.

whereas the expression of the short form of the prolactin receptor is very low or absent [23]; and (ii) following BDL, the genetic expression of the long form markedly increases in IBDU whereas the short form of prolactin receptor slightly increased in IBDU [23]. The slight difference between these data is presumably due to the different strain of rats used in our studies (female 344 Fischer) and the other studies (albino mongrel) [23]. Prolactin receptors are expressed by rat hepatocytes in the sinusoidal domain of cellular membranes and in perinuclear areas [32]. Prolactin receptors are also expressed by human hepatocytes of patients with obstructive jaundice of different etiology, but prolactin receptor expression is lower in hepatocytes compared to human cholangiocytes [21]. Although these previous studies have shown that cholangiocytes express prolactin receptors $[21,23]$, no information exists on the role of prolactin in the regulation of cholangiocyte hyperplasia.

We next performed in vivo studies and demonstrated that the administration of: (i) prolactin to normal female rats induces cholangiocyte hyperplasia devoid of portal inflammation and hepatic damage; and (ii) anti-prolactin antibody to BDL female rats decreases cholangiocyte proliferation and ameliorates portal inflammation and hepatic damage. The most likely explanation why prolactin increased cholangiocyte growth but not portal inflammation and hepatic damage in normal rats is that prolactin induces cholangiocyte hyperplasia as a direct effect and not as a consequence of obstructive cholestasis (i.e., BDL), a pathological condition associated with increased portal inflammation [33,34]. In support of our findings, a number of studies have shown that certain bile acids, vascular endothelial growth factor and forskolin induce cholangiocyte hyperplasia devoid of apoptosis, necrosis, hepatic damage or portal inflammation $[31,35,36]$. However, in $\mathrm{BDL}$, which is accompanied by an inflammatory response along with cholestasis $[33,37,38]$, the blocking of prolactin with an antibody reduces hepatic damage and cholangiocyte proliferation along with suppression of some inflammatory responses.

Concomitant with enhanced ductal hyperplasia, there was increased prolactin serum levels in normal female rats treated with prolactin compared to $\mathrm{NaCl}$ treated rats. In BDL female rats, the serum levels of prolactin increased approximately 15-fold as compared to the levels of normal female rats. Moreover, the administration of anti-prolactin antibody to BDL rats reduces not only cholangiocyte proliferation but also prolactin serum levels. We suggest that changes in prolactin serum levels may be important in the regulation of cholangiocyte growth in chronic cholestatic liver diseases.

In different cell types, prolactin effects are mediated by an increase in $\mathrm{Ca}^{2+}$ levels and PKC activation $[11,39]$. Thus, we evaluated the role of the $\mathrm{Ca}^{2+} / \mathrm{PKC}$ signaling pathway in prolactin regulation of cholangiocyte hyperplasia. Our results show that $\left[\mathrm{Ca}^{2+}\right]_{\mathrm{i}}$ levels are increased in normal female cholangiocytes after in vitro prolactin stimulation as compared to cholangiocytes stimulated with BSA. From our previous experience with purified cholangiocytes and cholangiocarcinoma cell lines we do not expect a traditional calcium spike $[24,26,29,40,41]$. In our previous studies $[24,26,29,40,41]$, we demonstrated that the $\mathrm{Ca}^{2+}$ dynamics of cholangiocytes are in general slower and not characterized by a $\mathrm{Ca}^{2+}$ spike $[24,26,29,40,41]$. The method that we currently employ results in $\mathrm{Ca}^{2+}$ measure- 


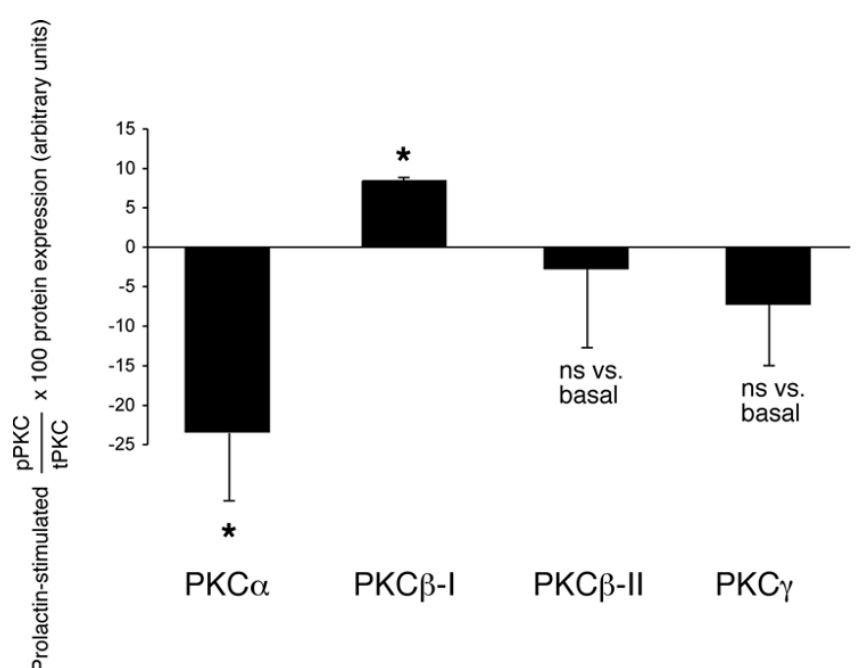

Figure 6

In vitro effect of prolactin on the phosphorylation of $\mathrm{Ca}^{2+}$ dependent PKC isoforms. Immunoblots for PKC- $\alpha$, PKC- $\beta-$ I, PKC- $\beta$-II and PKC- $\gamma$ in normal female cholangiocytes stimulated for 90 minutes at $37^{\circ} \mathrm{C}$ with $0.2 \%$ BSA (basal value) or prolactin (100 nM) with $0.2 \%$ BSA. When cholangiocytes were treated with prolactin, there was an increase in the phosphorylation of PKC $\beta$-I and a marked decrease in PKC $\alpha$ phosphorylation; no significant changes in the phosphorylation of PKC $\beta$-II and PKC $\gamma$ were observed in normal female cholangiocytes treated with prolactin or $0.2 \%$ BSA. Data are mean \pm SEM of 3 experiments. * $p<0.05$ vs. corresponding basal values. $\mathrm{PKC}=$ protein kinase $\mathrm{C}$.

ments [29,31], which are an average signal of 400,000 cells rather than typical single cell measurements $[24,26,40]$. This approach gives us similar data $[29,31]$ to that obtained with measurements, which were made in single cells loaded with Fluo-3AM [24,26,40]. Since the measurements are taken in a large number of cells the cellular response to prolactin is not synchronized in the studies. Thus, any peak(s) present will be muted and spread out over time, which is a factor contributing to the slow drift observed. In support of our finding, Ducret et al. demonstrated a similar slow response calcium wave due to prolactin in glia cells [42].

We next evaluated if prolactin stimulation of cholangiocyte proliferation was coupled with phosphorylation/ dephosphorylation of specific $\mathrm{Ca}^{2+}{ }^{2+}$ dependent PKC isoforms. Our finding that prolactin stimulation of normal female cholangiocyte proliferation is associated with concomitant increased (PKC $\beta-\mathrm{I})$ and decreased (PKC $\alpha$ ) PKC phosphorylation suggests that a counterbalancing system between PCK $\beta$ isoform and PKC $\alpha$ may regulate cholangiocyte proliferation following prolactin stimulation. In support of this concept, while enhanced phosphorylation of PKC $\beta$-II mediates the activation of secretin-stimulated ductal secretion [29] (a functional marker of cholangiocyte growth) $[1,2,4,6,25,43]$ of BDL rats, increased phosphorylation of PKC $\alpha$ (which is inversely related to cholangiocyte growth) is associated with reduced cholangiocyte growth $[24,25,40]$. In agreement with the view, in hematopoietic [44] and glioma [45] cells, the activation of PKC $\beta$-I and $\beta$ II isoforms leads to an increase in cell proliferation. Furthermore, in intestinal cell lines the overexpression and/or activation of PKC $\alpha$ decreases cell growth and tumorigenicity [46]. Taken together, our studies show that the $\mathrm{Ca}^{2+} / \mathrm{PKC} \beta-\mathrm{I}$ and $\alpha$ signaling pathway is one of the players involved in prolactin regulation of cholangiocyte proliferation, but did not evaluate if other pathways (e.g., JAK/STAT and 17-hydroxy-steroid dehydrogenase) modulate prolactin effects on cholangiocyte growth. Also, our studies do not establish which isoform (short or long) of the prolactin receptor mediates the effects of prolactin on cholangiocyte growth. However, based upon previous studies showing that the long form of prolactin receptor mediates increases in $\left[\mathrm{Ca}^{2+}\right]_{\mathrm{i}}$ in other cells $[18,19,47]$, we propose that the long form of the prolactin receptor may be the major player in prolactin modulation of cholangiocyte growth.

Next, we demonstrated that normal and BDL female cholangiocytes express the message and protein for prolactin and secrete prolactin in primary cultures. The reason why prolactin secretion is similar in normal and BDL female cholangiocytes (although prolactin message expression increases in BDL cholangiocytes) may be due to post-transcriptional events (e.g., message stability/degradation) affecting the translation of the prolactin message. On the basis of these findings, although our studies do not provide direct evidence for the following concept, we propose that prolactin may regulate cholangiocyte proliferation by an autocrine mechanism (in addition to a paracrine pathway). In agreement with the latter concept, a number of cells including mammary epithelial cells, fibroblasts, and cancer cell lines $[12,15]$ secrete prolactin, thus regulating their functions. Furthermore, in support of the concept that prolactin regulates cholangiocyte proliferation by an autocrine mechanism, we have previously shown that cholangiocytes express/secrete neurotrophins [33], vascular endothelial growth factor [31] and serotonin [48], thus regulating intrahepatic ductal mass by an autocrine mechanism $[31,33,48]$.

\section{Conclusion}

In summary this study has shown that: (i) cholangiocytes express both isoforms (long and short) of the receptor for prolactin; (ii) prolactin has a trophic effect on the growth of normal female cholangiocytes by phosphorylation of PKC $\beta$-I and dephosphorylation of PKC $\alpha$; and (iii) cholangiocytes express the message/protein for and secrete prolactin, findings suggesting that prolactin participates, by an 


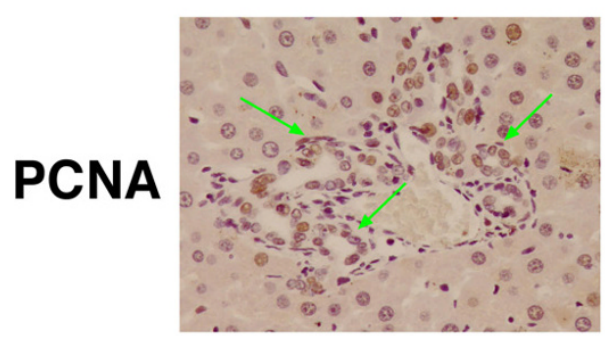

$\mathrm{BDL}+$ nonimmune serum

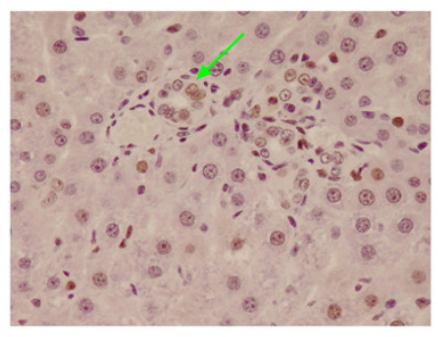

$\mathrm{BDL}+$ anti-prolactin antibody
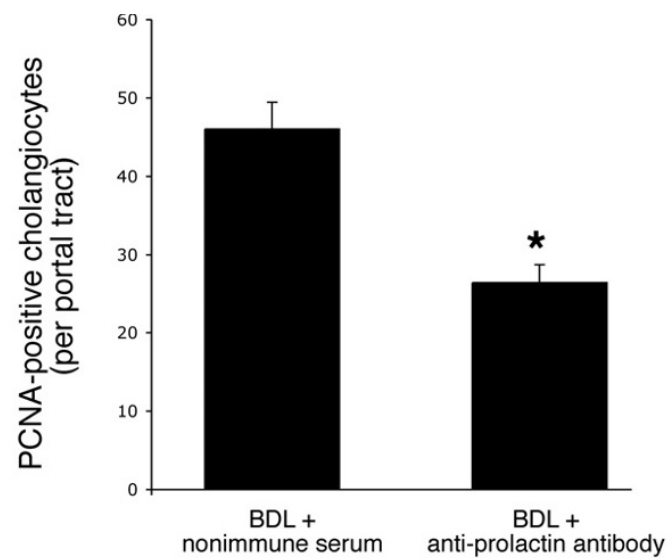

$\mathrm{BDL}+$ nonimmune serum

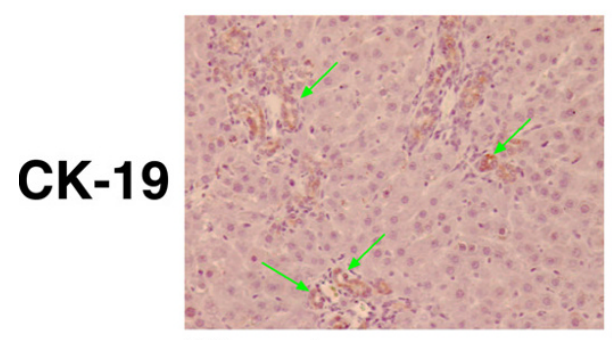

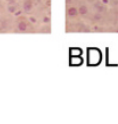

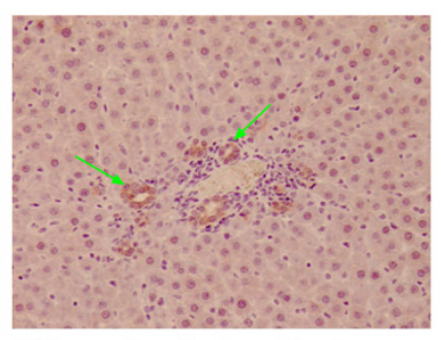

$\mathrm{BDL}+$ anti-prolactin antibody
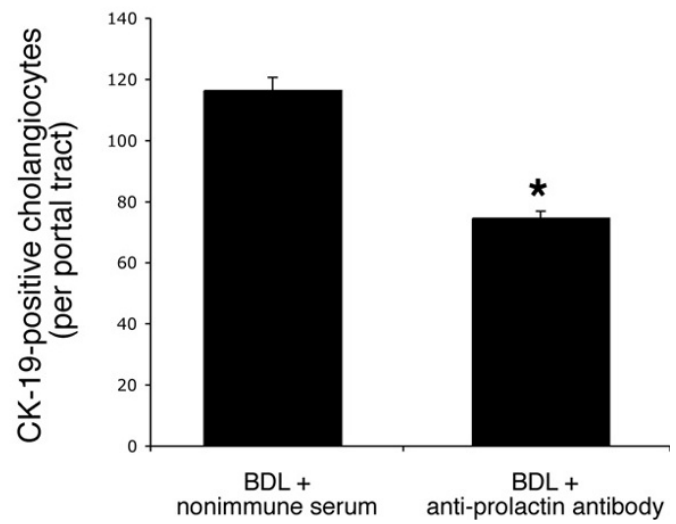

\section{Figure 7}

Administration of anti-prolactin antibody to female BDL rats decreased the number of [top panel] PCNA-positive cholangiocytes and [lower panel] CK-19-positive cholangiocytes compared to cholangiocytes from BDL female rats treated with nonimmune serum. Orig. magn., $\times 20(P C N A)$ and $\times 10(C K-19)$. Data are mean \pm SEM of 5 values obtained from the 3 slides evaluated per each group of animal. $* p<0.05$ vs. the corresponding value of $B D L$ rats treated with non-immune serum.

autocrine mechanism, in the modulation of cholangiocyte proliferation. Prolactin may be an important therapeutic approach for the management of cholangiopathies.

\section{Methods \\ Materials}

Reagents were purchased from Sigma Chemical (St Louis, MO) unless otherwise indicated. The RIA kit for the measurement of prolactin levels in serum and cholangiocyte supernatant was purchased from GE Healthcare Bio-Sciences Corp. (Piscataway, NJ). The monoclonal mouse antibody against PCNA was purchased from DAKO (Kyoto, Japan). PCNA is a nonhistone nuclear protein that plays an important role in DNA replication and cellular proliferation by interacting with DNA polymerasedelta) [49]. The substrate for $\gamma$-glutamyl transpeptidase $(\gamma$ GT), N ( $\gamma$-L-glutamyl)-4-methoxy-2-naphthylamide was purchased from Polysciences (Warrington, PA). Antibodies against prolactin and the $\mathrm{Ca}^{2+}$-dependent PKC isoforms $(\alpha, \beta-I, \beta-$ II and $\gamma)$ were purchased from Santa Cruz Biotechnology Inc. (Santa Cruz, CA). The sheep polyclonal (ab35349) antibody recognizing the prolactin receptor (used for the immunohistochemical and immunofluorescent evaluation of prolactin receptor in liver sections) was purchased from Abcam (Cambridge, UK). This antibody does not distinguish between the short or long form of the prolactin receptor. The RNeasy Mini Kit to extract total RNA from purified cholangiocytes was purchased from Qiagen Inc, Valencia, CA.

\section{Experimental model}

Female or male Fisher rats (150-175 gm) were purchased from Charles River (Wilmington, MA) and maintained in a temperature-controlled environment $\left(20-22^{\circ} \mathrm{C}\right)$ with a 

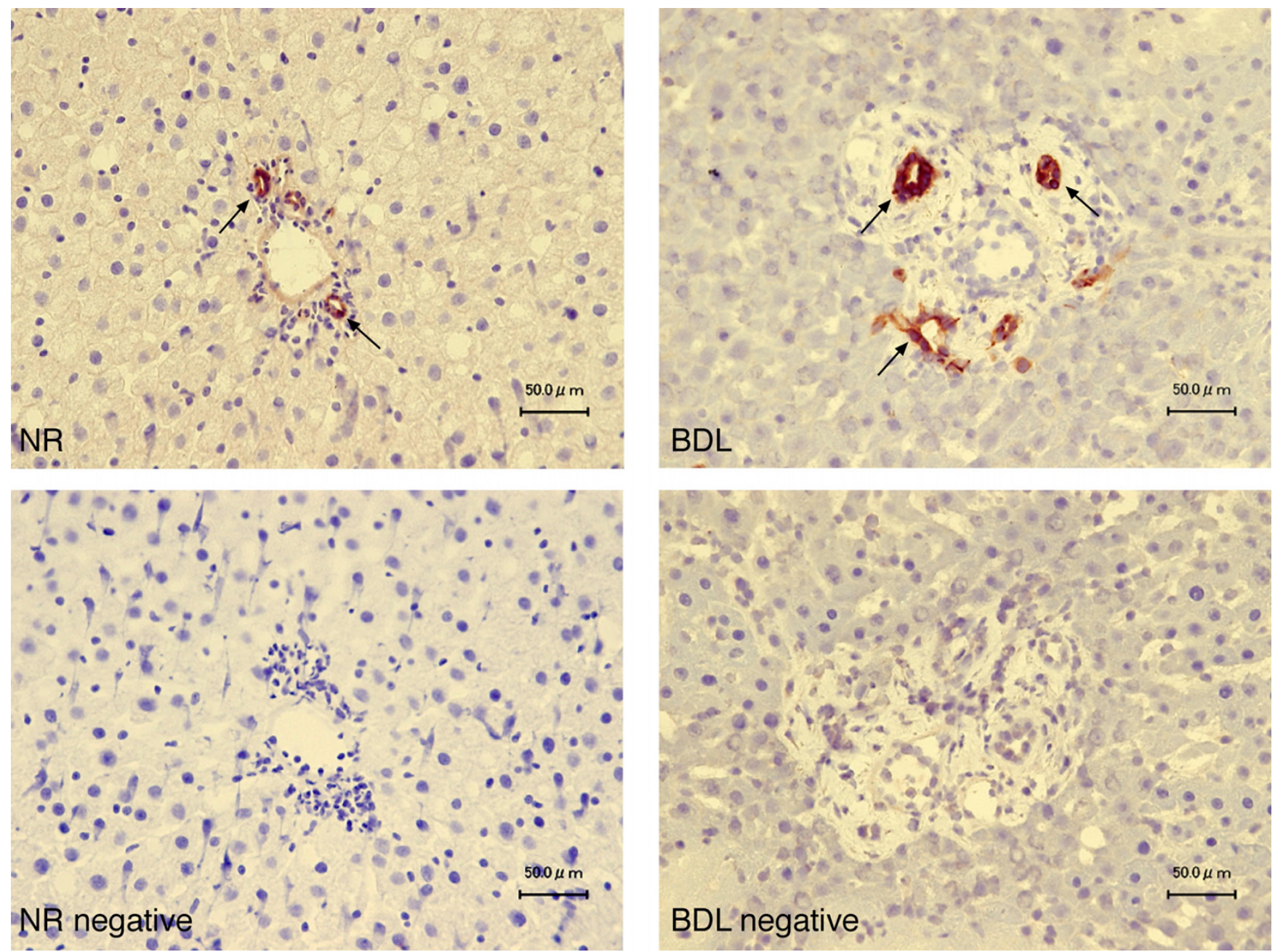

\section{Figure 8}

Immunohistochemistry for prolactin in liver sections of normal and BDL female rats shows that intrahepatic bile ducts express the protein for prolactin (arrows). Bar $=50 \mu \mathrm{m}$.

12:12-hour light-dark cycle. Rats were fed ad libitum standard chow and had free access to drinking water. To evaluate the in vivo effect of prolactin on cholangiocyte growth, normal female or male rats were injected twice per day with $\mathrm{NaCl}$ or ovine prolactin $(420 \mu \mathrm{g} / \mathrm{rat}$ per day, a dose similar to that used in other studies in rodents) [50] for 1 week. We evaluated the effect of the administration of anti-prolactin antibody on cholangiocyte proliferation of BDL female or male rats. Immediately after BDL [43], rats received $200 \mu \mathrm{L}$ of non-immune serum or polyclonal neutralizing prolactin antibody $(400 \mathrm{pg} /$ dose, intraperitoneally every day) [51] for 7 days. Before each experimental procedure, animals were injected with sodium pentobarbital $(50 \mathrm{mg} / \mathrm{kg}$ weight, IP). Study protocols were performed in compliance with the institutional guidelines.

\section{Purification of cholangiocytes}

Cholangiocytes were isolated by immunoaffinity separation $[1,2,25,52,53]$, using a mouse monoclonal antibody (IgM, provided by Dr. R. Faris, Brown University, Providence, RI) that recognizes an unidentified antigen expressed by all intrahepatic rat cholangiocytes [52]. The purity of cholangiocytes was evaluated by $\gamma$-GT histochemistry [30]. Cell viability (by trypan blue exclusion) ranged from 95 to $98 \%$.

\section{Expression of prolactin receptors in cholangiocytes}

For immunohistochemistry, after deparaffination of liver sections ( $5 \mu \mathrm{m}$ thick; 3 slides analyzed per group), endogenous peroxidase activity was quenched for 5 minutes with methanol-peroxide solution $(0.3 \%$ hydrogen peroxide solution, Santoku Chemical Industries, Tokyo, Japan) in $80 \%$ methanol (WAKO, Osaka, Japan). Sections were 

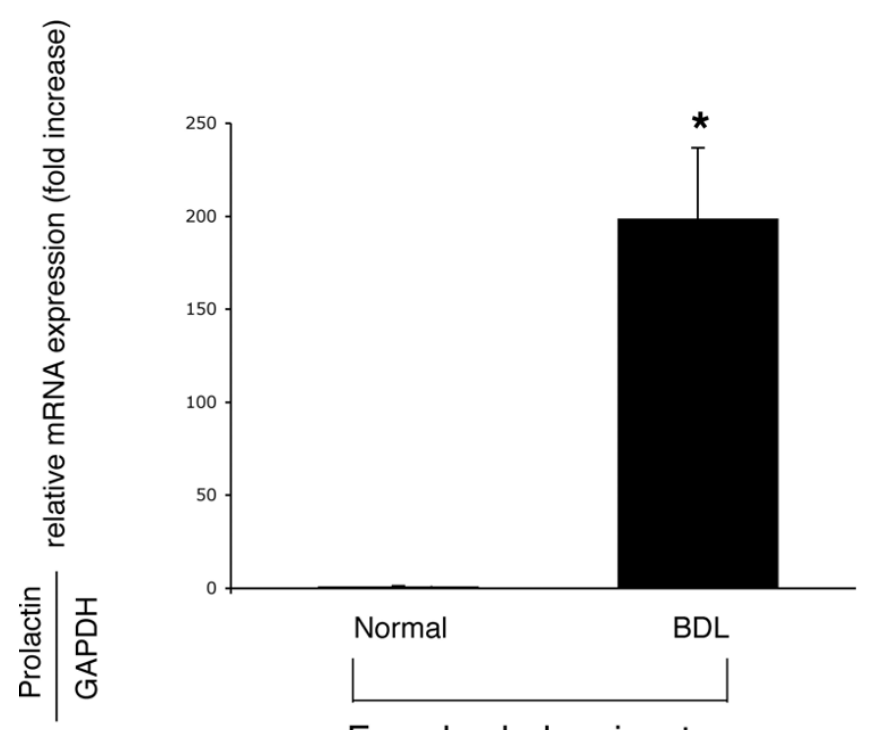

Female cholangiocytes
Figure 9

Real time PCR for prolactin mRNA in total RNA from normal and BDL female cholangiocytes. We demonstrated that: (i) female normal cholangiocytes express prolactin mRNA at low levels; and (ii) following BDL, prolactin mRNA markedly increased in female cholangiocytes. Data are mean \pm SEM of 3 experiments. ${ }^{*} p<0.05$ vs. relative expression of prolactin receptor of normal female cholangiocytes.

hydrated in graded alcohol and rinsed in $1 \times$ phosphatebuffered saline ( $1 \times$ PBS, pH 7.4) before applying the antibody specific for prolactin receptor (diluted 1:400) or non-immune serum at $4{ }^{\circ} \mathrm{C}$ overnight. After rinsing with PBS, Histofine Simple Stain Rat (Multi) (Nichirei, Tokyo, Japan) was added as secondary antibody for 1 hour at room temperature. Nuclear counterstaining was performed using hematoxylin for light microscopy after detecting reactions with VECTOR NovaRED (Vector Laboratories, Inc., Burlingame, CA). Following staining, sections were observed with the light microscope ECLIPSE E600 (Nikon, Tokyo, Japan).

For immunofluorescence, frozen liver sections $(20 \mu \mathrm{m}$ thick; $\mathrm{n}=3$ per each group of animals) were fixed in $4 \%$ paraformaldehyde (in $1 \times$ PBS) for 10 minutes, followed by tissue permeabilization in PBST $(1 \times$ PBS with $0.2 \%$ triton X-100). Non-specific protein binding was blocked by $5 \%$ normal goat serum. Following incubation with a primary antibody against prolactin receptor (raised in sheep, 1:5; Abcam) or non-immune goat serum (negative control), together with an anti CK-19 antibody (raised in mouse, 1:50; Vision Biosystems Inc, Norwell, MA), sections were rinsed with $1 \times$ PBS and subsequently incubated with Cy2-conjugated anti-mouse and Cy3conjugated anti-sheep antibodies (both diluted at 1:50) (Jackson Immunochemicals, West Grove, PA). Following staining, sections were observed either with the light microscope ECLIPSE E600 (Nikon, Kawasaki, Japan) or fluorescence microscope DMRXA/HC (Leica, Tokyo, Japan).

We first performed RT-PCR for the short and long form of prolactin receptor to determine that cholangiocytes express the expected molecular weight band for these two receptor isoforms and GAPDH, the housekeeping gene [1]. Thereafter, the same primers were used to determine (by real time PCR) the quantitative expression of short and long prolactin receptors in total RNA $(0.75 \mu \mathrm{g})$ from normal and BDL female cholangiocytes. The primers (from Integrated DNA Technologies, Coralville, IA) were designed according to the sequences for the short (NCBI Genbank Accession No. NM 012630) [23] and long prolactin receptor mRNAs (NCBI Genbank Accession No. $\underline{\text { NM }}$ 001034111) [23]. The 5' primer, 5'-CAAATGGGAAGCAGTTCCTC-3' (common) was designed to a region that is homologous to both the short and long forms. The short form 3' primer, 5'-AGGAAGGGCCAGGTACAGAT-3' (short), was taken from a sequence region of the short form mRNA that is non-homologous to long form mRNA. The long form 3' primer, 5'-GGGGTTCCTCACACTTTTCA3' (long), was taken from a sequence region of the long form mRNA that is non-homologous to the short form mRNA. The primers for GAPDH (sense 5'-GTGACTTCAACAGCAACTCCCATTC-3' and antisense 5'-GTTATGGGGTCTGGGATGGAATTGTG-3', 294 bp) were based on the rat GAPDH sequence [54]. Standard RT-PCR conditions were used with $1 \mu \mathrm{g}$ of total mRNA (35 step cycles: $30 \mathrm{sec}$ at $94^{\circ} \mathrm{C}, 30 \mathrm{sec}$ at $59^{\circ} \mathrm{C}$ and $45 \mathrm{sec}$ at $72^{\circ} \mathrm{C}$ ). The PCR samples for prolactin receptor short (582 bp) and long (781 bp) forms were run on agarose gels, the bands excised and removed from the gel with the Qiaquick Gel Extraction Kit (Qiagen, Valencia, CA). The purified fragments were sequenced by Davis Sequencing (Davis, CA).

We used the RT ${ }^{2}$ Real-Time assay from SuperArray (Frederick, MD) to evaluate the expression of the short and long form of prolactin receptor mRNA in female cholangiocytes from normal and BDL rats. RNA was reverse transcribed using the Reaction Ready ${ }^{\mathrm{TM}}$ First Strand cDNA synthesis kit (SuperArray). As described previously [55], 1 $\mu \mathrm{l}$ of the cDNA template was added to $12.5 \mu \mathrm{l}$ of master mix, $10.5 \mu \mathrm{l}$ of DI water and $1 \mu \mathrm{l}$ of $\mathrm{RT}^{2}$ PCR rat primers (SuperArray, Frederick, MD) designed specifically for the messages for short and long prolactin receptor (Integrated DNA Technologies, Coralville, IA) and GAPDH (SuperArray). A $\Delta \Delta \mathrm{CT}$ analysis was performed using the normal pooled cholangiocytes as the control sample. Data was expressed as relative mRNA levels \pm SEM of short or long prolactin receptor to GAPDH ratio $(n=3)$. To confirm the presence of one PCR product (by real time PCR analysis), 
we performed a dissociation analysis and observed the presence of only one peak for all primers.

\section{Evaluation of portal inflammation, lobular damage, necrosis and cholangiocyte apoptosis and proliferation} We evaluated the effect of in vivo administration of: (i) $\mathrm{NaCl}$ or prolactin to normal rats; and (ii) anti-prolactin antibody or non-immune serum to BDL rats on portal inflammation, lobular damage, necrosis and cholangiocyte apoptosis and proliferation. Paraffin embedded liver sections ( $5 \mu \mathrm{m}, 3$ sections analyzed per group) were stained with hematoxylin and eosin (H\&E) before determining lobular damage, necrosis and the degree of portal inflammation as previously described by us [41]. Terminal deoxynucleotidyl transferase biotin-dUTP nick end labeling (TUNEL) analysis was performed using a commercially available apoptosis detection kit TACS $^{\mathrm{TM}} \mathrm{TdT}$ kit, R\&D systems, Minneapolis, MN). Following the selected staining, sections ( $5 \mu \mathrm{m}, 3$ slides analyzed per group) were evaluated in coded fashion with the microscope ECLIPSE E600 (Nikon Eclipse, Tokyo, Japan). Two hundred cells per slide were counted in a coded fashion in ten non-overlapping fields.

Cholangiocyte proliferation was evaluated by quantitative determination of the number of PCNA- and CK-19-positive cholangiocytes in liver sections from the selected groups of animals. Immunohistochemistry for PCNA or CK-19 was performed in paraffin-embedded sections ( 5 $\mu \mathrm{m}, 3$ slides analyzed for each group) as described $[2,5]$. Sections were counterstained with hematoxylin and examined with the ECLIPSE E600 microscope (Nikon Eclipse, Tokyo, Japan). Over 100 cholangiocytes were counted in a random, blinded fashion in three different fields for each section. Data were expressed as number of PCNA- or CK-19-positive cholangiocytes per each 100 cholangiocytes.

\section{Evaluation of the intracellular signaling pathway by which prolactin regulates normal cholangiocyte proliferation}

We performed in vitro experiments in normal female cholangiocytes to demonstrate that: (i) prolactin increases intracellular $\mathrm{Ca}^{2+}$ levels; and (ii) specific $\mathrm{Ca}^{2+}$-dependent PKC isoforms play a role in prolactin regulation of cholangiocyte proliferation. Following purification, cholangiocytes were incubated for 1 hour at $37^{\circ} \mathrm{C}$ to regenerate membrane proteins $[1,6,24-26,29,56]$ damaged by proteolytic enzymes during isolation [52] prior to loading with Fluo-3AM before $\left[\mathrm{Ca}^{2+}\right]_{\mathrm{i}}$ measurements. A number of studies have demonstrated that following the incubation time of 1 hour at $37^{\circ} \mathrm{C}$ cholangiocytes are functionally responsive $[1,26,29,33,52,56]$. $\left[\mathrm{Ca}^{2+}\right]_{\mathrm{i}}$ fluorescence measurements in cholangiocytes were performed using fluo-3 AM (Molecular Probes, Eugene, Oregon) and a Fluoroskan Ascent FL (ThermoLabsystems, Helsinki,
Finland) microplate reader equipped with three injectors $[29,57]$. Cholangiocytes $\left(4 \times 10^{4}\right.$ per well) were loaded for 1 hour at room temperature with $5 \mu \mathrm{M}$ of fluo-3 AM in Tyrode's salt solution (TSS, $137 \mathrm{mM} \mathrm{NaCl}, 2.7 \mathrm{mM} \mathrm{KCl}, 1$ $\mathrm{mM} \mathrm{MgCl}{ }_{2}, 0.2 \mathrm{mM} \mathrm{NaH} \mathrm{PO}_{4}, 12 \mathrm{mM} \mathrm{NaHCO}_{3}$ and 5.5 $\mathrm{mM}$ glucose) with O.1\% Pluronic F-127 (Molecular Probes, Eugene, Oregon). After washes with TSS, the loaded cells were added to a 96 well black microplate. The baseline fluorescence was measured 50 times after 1 second at 2-second intervals. TSS alone or prolactin (100 $\mathrm{nM}$ ) dissolved in buffer was injected sequentially into separate wells, and the fluorescence intensity was measured at $538 \mathrm{~nm}$ for 3 minutes at 1 -second intervals. The excitation wavelength was $485 \mathrm{~nm}$. $\left[\mathrm{Ca}^{2+}\right]_{\mathrm{i}}$ concentration was calculated as follows: $\left[\mathrm{Ca}^{2+}\right]_{i}=\mathrm{K}_{\mathrm{d}}\left(\mathrm{F}-\mathrm{F}_{\min }\right) /\left(\mathrm{F}_{\max }-\mathrm{F}\right) . \mathrm{F}_{\max }$ refers to fluorescence intensity measured after permeabilization of the cells with 1\% NP-40. Then, 0.1 M EGTA was added to chelate $\mathrm{Ca}^{2+}$ and minimum fluorescence intensity $\left(\mathrm{F}_{\min }\right)$ was obtained. Ionomycin $(10 \mu \mathrm{M})$ was utilized at the end of each calcium determination to ensure cholangiocyte responsiveness.

Purified normal female cholangiocytes were stimulated for 90 minutes [25-27] at $37^{\circ} \mathrm{C}$ with $0.2 \%$ BSA (basal) or prolactin (100 nM) with $0.2 \%$ BSA, and analyzed for protein expression of the phosphorylated form (expressed as ratio to total protein expression of the corresponding PKC isoform) of the selected PKC isoform by immunoblots. The intensity of the bands was determined by scanning video densitometry using the phospho-imager, Storm 860, Amersham Biosciences (Piscataway, NJ) using the ImageQuant TLV 2003.02 (Little Chalfont, Buckinghamshire UK).

\section{Evaluation of expression and secretion of prolactin by cholangiocytes}

We performed immunohistochemistry (in liver sections) to evaluate if female cholangiocytes from normal and $\mathrm{BDL}$ rats express the protein for prolactin. Immunohistochemistry for prolactin in liver sections was performed in the same manner as described for prolactin receptor staining except using a goat polyclonal anti-prolactin as primary antibody.

We evaluated by real time PCR the quantitative expression of prolactin in total RNA $(0.75 \mu \mathrm{g})$ from purified cholangiocytes from normal and BDL female and male rats. Real time PCR for prolactin was performed as described above for prolactin receptor with the exception of the primers that were purchased from SuperArray.

To determine the amount of prolactin secreted, purified cholangiocytes from normal and BDL female rats were incubated at $37^{\circ} \mathrm{C}$ for zero and six hours. Thereafter, cells were centrifuged at $1,500 \mathrm{rpm}$ for 10 minutes at $4^{\circ} \mathrm{C}$, the 
supernatant transferred to a clean tube and stored at $70^{\circ} \mathrm{C}$ before analysis for prolactin levels by RIA by commercially available kits (GE Healthcare Bio-Sciences Corp.).

\section{Statistical analysis}

We expressed all data as mean \pm SEM. The differences between groups were analyzed by Student's t-test if two groups were analyzed or analysis of variance (ANOVA) if more than two groups were analyzed (assuming $\mathrm{p}<0.05$ as statistical difference between the analyzed groups).

\section{Abbreviations}

$\mathrm{BSA}=$ bovine serum albumin; $\mathrm{BDL}=$ bile duct ligation; CK-19 = cytokeratin-19; GAPDH = glyceraldehyde-3phosphate dehydrogenase; $\gamma$-GT $=\gamma$-glutamyl transpeptidase; $\mathrm{MAPK}=$ mitogen-activated protein kinase; $\mathrm{PCNA}=$ proliferating cellular nuclear antigen; $\mathrm{PBC}=$ primary biliary cirrhosis; $\mathrm{PKC}=$ protein kinase $\mathrm{C}$.

\section{Authors' contributions}

ST has made substantial contributions to the conception and writing of the study.

SG has measured intracellular $\mathrm{Ca}^{2+}$ levels and made substantial contribution to the design and writing of the study.

HF has performed RIA analysis, real time PCR and made substantial contribution to the design and writing of the study.

SD has performed the immunofluorescence studies and made substantial contribution to the design and writing of the study.

YU has performed the immunohistochemical and morphometric analyses in liver sections.

DA has made substantial contribution to the conception and writing of the study.

LM has made substantial contribution to the conception and writing of the study.

MM has made substantial contribution to the conception and writing of the study.

GF has made substantial contribution to the conception and writing of the study.

JV has performed RIA analysis and stimulated all the purified cholangiocytes with the selected agonists/antagonists.
SV has performed all the immunoblots.

BV has performed all the cholangiocyte isolations.

IP-YL performed RNA extraction and RT-PCR analysis.

VH-YL performed RNA extraction and RT-PCR analysis.

EG has performed the immunohistochemical analyses for prolactin and prolactin receptor made substantial contribution to the editing of the manuscript.

GC has performed the immunohistochemical analyses for prolactin and prolactin receptor made substantial contribution to the editing of the manuscript.

$\mathrm{AB}$ has made substantial contributions to the conception and writing of the study.

GA has made substantial contributions to the conception, design and writing of the study. He oversaw the entire project.

All authors have read and approved the final manuscript.

\section{Acknowledgements}

This work was supported by the Dr. Nicholas C. Hightower Centennial Chair of Gastroenterology from Scott \& White Hospital, a VA Research Scholar Award and VA Merit award to Dr. Alpini, by the MIUR grants 2005067975_004 and 2005062350_003 to the Department of Gastroenterology, Università Politecnica delle Marche, by a Grant from MIUR (PRIN 2005 \#2005067975_002) Dr. Alvaro, and by Health and Labour Sciences Research Grants (from the Ministry of Health, Labour and Welfare of Japan) for the Research on Measures for Intractable Diseases and GRANTIN-AID FOR SCIENTIFIC RESEARCH C (I6590573) from JSP to Dr. Ueno.

We would like to thank Meg Chrisler and Glen Cryer, Division of Communication, Scott \& White, for their assistance in editing the manuscript.

\section{References}

I. Alpini G, Glaser S, Ueno Y, Pham L, Podila PV, Caligiuri A, LeSage G, LaRusso NF: Heterogeneity of the proliferative capacity of rat cholangiocytes after bile duct ligation. Am J Physiol Gastrointest Liver Physiol 1998, 274:G767-G775.

2. LeSage G, Glaser S, Gubba S, Robertson WE, Phinizy JL, Lasater J, Rodgers RE, Alpini G: Regrowth of the rat biliary tree after $\mathbf{7 0 \%}$ partial hepatectomy is coupled to increased secretininduced ductal secretion. Gastroenterology 1996, I I I: I633-1644.

3. Alvaro D, Mancino MG, Glaser S, Gaudio E, Marzioni M, Francis H, Alpini G: Proliferating cholangiocytes: a neuroendocrine compartment in the diseased liver. Gastroenterology 2007, 132:415-431.

4. Alpini G, Prall RT, LaRusso NF: The pathobiology of biliary epithelia. In The Liver; Biology \& Pathobiology 4th edition. Edited by: Arias IM, Boyer JL, Chisari FV, Fausto N, Jakoby W, Schachter D, Shafritz DA. Philadelphia, PA: Lippincott Williams \& Wilkins; 200 I:42 I-435.

5. LeSage G, Glaser S, Ueno Y, Alvaro D, Baiocchi L, Kanno N, Phinizy $J$, Francis H, Alpini G: Regression of cholangiocyte proliferation after cessation of ANIT feeding is coupled with increased apoptosis. Am J Physiol Gastrointest Liver Physiol 200I, 28I:GI82-GI90.

6. LeSage G, Glaser S, Marucci L, Benedetti A, Phinizy JL, Rodgers R, Caligiuri A, Papa E, Tretjak Z, Jezequel AM, et al.: Acute carbon tet- 
rachloride feeding induces damage of large but not small cholangiocytes from BDL rat liver. Am J Physiol Gastrointest Liver Physiol 1999, 276:GI289-GI30I.

7. Alvaro D, Invernizzi $P$, Onori $P$, Franchitto $A$, De Santis A, Crosignani A, Sferra R, Ginanni-Corradini S, Mancino MG, Maggioni M, et al.: Estrogen receptors in cholangiocytes and the progression of primary biliary cirrhosis. J Hepatol 2004, 41:905-912.

8. Alvaro D, Alpini G, Onori P, Perego L, Svegliati Baroni G, Franchitto A, Baiocchi L, Glaser S, Le Sage G, Folli F, et al.: Estrogens stimulate proliferation of intrahepatic biliary epithelium in rats. Gastroenterology 2000, I 19:168I-1691.

9. Kaplan MM, Gershwin ME: Primary biliary cirrhosis. N Engl] Med 2005, 353:| $26|-| 273$

10. Alvaro D, Alpini G, Onori P, Franchitto A, Glaser S, Le Sage G, Gigliozzi A, Vetuschi A, Morini S, Attili AF, et al.: Effect of ovariectomy on the proliferative capacity of intrahepatic rat cholangiocytes. Gastroenterology 2002, I 23:336-344.

II. Fresno Vara JA, Caceres MA, Silva A, Martin-Perez J: Src family kinases are required for prolactin induction of cell proliferation. Mol Biol Cell 200I, I 2:2I7I-2I83.

12. Goffin V, Binart N, Touraine P, Kelly PA: Prolactin: the new biology of an old hormone. Annu Rev Physiol 2002, 64:47-67.

13. Mitev V, Bayat-Sarmadi M, Lemnaouar M, Puissant C, Houdebine LM: The effect of prolactin on casein kinase II, MAP kinase and PKC in rabbit mammary cells and $\mathbf{N b 2}$ rat lymphoid cells. Biochem Pharmacol 1996, 52:1719-1927.

14. Selvaraj NG, Omi E, Gibori G, Rao MC: Janus kinase 2 (JAK2) regulates prolactin-mediated chloride transport in mouse mammary epithelial cells through tyrosine phosphorylation of $\mathrm{Na}^{+}-\mathrm{K}^{+}-2 \mathrm{Cl}^{-}$cotransporter. Mol Endocrinol 2000, 14:2054-2065

15. Bole-Feysot C, Goffin V, Edery M, Binart N, Kelly PA: Prolactin (PRL) and its receptor: actions, signal transduction pathways and phenotypes observed in PRL receptor knockout mice. Endocr Rev 1998, 19:225-268.

16. Duan WR, Parmer TG, Albarracin CT, Zhong L, Gibori G: PRAP, a prolactin receptor associated protein: its gene expression and regulation in the corpus luteum. Endocrinology 1997, 138:3216-3221.

17. Nokelainen P, Peltoketo H, Vihko R, Vihko P: Expression cloning of a novel estrogenic mouse 17 beta-hydroxysteroid dehydrogenase/ I 7-ketosteroid reductase ( $\mathrm{m}$ I 7HSD7), previously described as a prolactin receptor-associated protein (PRAP) in rat. Mol Endocrinol 1998, 12:1048-1059.

18. Ratovondrahona D, Fahmi M, Fournier B, Odessa MF, Skryma R, Prevarskaya $N$, Djiane J, Dufy $B$ : Prolactin induces an inward current through voltage-independent $\mathrm{Ca}^{2+}$ channels in Chinese hamster ovary cells stably expressing prolactin receptor. I Mol Endocrinol 1998, 21:85-95.

19. Ratovondrahona D, Fournier B, Odessa MF, Dufy B: Prolactin stimulation of phosphoinositide metabolism in $\mathrm{CHO}$ cells stably expressing the PRL receptor. Biochem Biophys Res Commun 1998, 243:127-130. Erratum in: 1998 Apr 1928;1245(1993):1948.

20. Kloehn S, Otte C, Korsanke M, Arendt T, Clemens A, Glasow A, Bornstein SR, Folsch UR, Monig H: Expression and distribution of the prolactin receptor in normal rat liver and in experimental liver cirrhosis. Horm Metab Res 200I, 33:394-40I.

21. Zenkova TY, Kulikov AV, Bogorad RL, Rozenkrants AA, Platonova LV, Shono NI, Gal'perin El, Smirnova OV: Expression of prolactin receptors in human liver during cholestasis of different etiology and secondary liver cancer. Bull Exp Biol Med 2003, 135:566-569.

22. Bogorad RL, Ostroukhova TY, Orlova AN, Rubtsov PM, Smirnova OV: Prolactin receptors in rat cholangiocytes: regulation of level and isoform ratio is sex independent. Biochemistry (Mosc) 2006, $71: 178-184$.

23. Bogorad RL, Ostroukhova TY, Orlova AN, Rubtsov PM, Smirnova $O V$ : Long isoform of prolactin receptor predominates in rat intrahepatic bile ducts and further increases under obstructive cholestasis. I Endocrinol 2006, I88:345-354.

24. Alpini G, Baiocchi L, Glaser S, Ueno Y, Marzioni M, Francis H, Phinizy JL, Angelico M, LeSage G: Ursodeoxycholate and tauroursodeoxycholate inhibit cholangiocyte growth and secretion of BDL rats through activation of PKC alpha. Hepatology 2002, 35: $104 \mid-1052$
25. Glaser S, Benedetti A, Marucci L, Alvaro D, Baiocchi L, N. K, Caligiuri A, Phinizy JL, Chowdhury U, Papa E, et al:: Gastrin inhibits cholangiocyte growth in bile duct-ligated rats by interaction with cholecystokinin-B/Gastrin receptors via D-myo-inositol I,4,5-triphosphate-, $\mathrm{Ca}\left({ }^{2+}\right)$-, and protein kinase $\mathrm{C}$ alphadependent mechanisms. Hepatology 2000, 32:17-25.

26. LeSage G, Marucci L, Alvaro D, Glaser S, Benedetti A, Marzioni M, Patel T, Francis H, Phinizy JL, Alpini G: Insulin inhibits secretininduced ductal secretion by activation of PKC alpha and inhibition of PKA activity. Hepatology 2002, 36:64I-65I.

27. Glaser S, Alvaro D, Roskams T, Phinizy JL, Stoica G, Francis H, Ueno Y, Barbaro B, Marzioni M, Mauldin J, et al: Dopaminergic inhibition of secretin-stimulated choleresis by increased PKCgamma expression and decrease of PKA activity. Am J Physio Gastrointest Liver Physiol 2003, 284:G683-G694.

28. Glaser S, Alvaro D, Ueno Y, Francis H, Marzioni M, Phinizy JL, Baumann B, Mancino MG, Venter J, LeSage G, et al:: Gastrin reverses established cholangiocyte proliferation and enhanced secretin-stimulated ductal secretion of BDL rats by activation of apoptosis through increased expression of $\mathrm{Ca}^{2+}$ - dependent PKC isoforms. Liver Int 2003, 23:78-88.

29. LeSage G, Alvaro D, Glaser S, Francis H, Marucci L, Roskams T, Phinizy JL, Marzioni M, Benedetti A, Taffetani S, et al.: Alpha-I adrenergic receptor agonists potentiate secretin-stimulated choleresis of bile duct ligated rats by $\mathrm{Ca}^{2+}$ and $\mathrm{PKC}$-dependent stimulation of cAMP synthesis. Hepatology 2004, 40:1 II6-II27.

30. Rutenburg AM, Kim H, Fischbein JW, Hanker JS, Wasserkrug HL, Seligman AM: Histochemical and ultrastructural demonstration of $\gamma$-glutamyl transpeptidase activity. J Histochem Cytochem 1969, 17:517-526.

31. Gaudio E, Barbaro B, Alvaro D, Glaser S, Francis H, Ueno Y, Meininger CJ, Franchitto A, Onori P, Marzioni M, et al.: Vascular endothelial growth factor stimulates rat cholangiocyte proliferation via an autocrine mechanism. Gastroenterology 2006, 130:1270-1282

32. Ouhtit A, Ronsin B, Kelly PA, Morel G. Ultrastructural expression of prolactin receptor in rat liver. Biol Cell 1994, 82:169-176.

33. Gigliozzi A, Alpini G, Baroni-Svegliati G, Marucci L, Glaser S, Francis $H$, Mancino M, Drudi Metalli V, Benedetti A, Attili A, et al.: Nerve growth factor modulates the proliferative capacities of the intrahepatic biliary epithelium in experimental cholestasis. Gastroenterology 2004, I 27: I 198-1209.

34. Demirbilek S, Tas E, Gurunluoglu K, Akin M, Aksoy RT, Emre MH, Aydin NE, Ay S, Ozatay N: Fluvastatin reduced liver injury in rat model of extrahepatic cholestasis. Pediatr Surg Int 2007, 23:155-162

35. Alpini G, Glaser S, Ueno Y, Rodgers R, Phinizy JL, Francis H, Baiocchi L, Holcomb LA, Caligiuri A, LeSage G: Bile acid feeding induces cholangiocyte proliferation and secretion: evidence for bile acid-regulated ductal secretion. Gastroenterology 1999, II 6:179-186.

36. Francis $\mathrm{H}$, Glaser $\mathrm{S}$, Ueno $\mathrm{Y}$, LeSage G, Marucci L, Benedetti A, Taffetani S, Marzioni M, Alvaro D, Venter J, et al.: cAMP stimulates the secretory and proliferative capacity of the rat intrahepatic biliary epithelium through changes in the PKA/Src/MEK/ ERK I/2 pathway. J Hepatol 2004, 4 I:528-537.

37. Roeb E, Purucker E, Gartung C, Geier A, Jansen B, Winograd R, Matern S: Effect of glutathione depletion and hydrophilic bile acids on hepatic acute phase reaction in rats with extrahepatic cholestasis. Scand J Gastroenterol 2003, 38:878-885.

38. Saito JM, Maher Jj: Bile duct ligation in rats induces biliary expression of cytokine-induced neutrophil chemoattractant. Gastroenterology 2000, I 18:1157-1168.

39. Bolander FFJ: Prolactin activation of mammary nitric oxide synthase: molecular mechanisms. J Mol Endocrinol 2002, 28:45-5I

40. Alpini G, Kanno N, Phinizy JL, Glaser S, Francis H, Taffetani S, LeSage $\mathrm{G}$ : Tauroursodeoxycholate inhibits human cholangiocarcinoma growth via $\mathrm{Ca}^{2+}$, PKC-, and MAPK-dependent pathways. Am J Physiol Gastrointest Liver Physiol 2004, 286:G973-982.

4I. Fava G, Ueno Y, Glaser S, Francis H, Demorrow S, Marucci L, Marzioni M, Benedetti A, Venter J, Vaculin B, et al:: Thyroid hormone inhibits biliary growth in bile duct ligated rats by $P L C / I P_{3} /$ $\mathrm{Ca}^{2+}$-dependent downregulation of Src/ERKI/2. Am 」 Physiol Cell Physiol 2007, 292:CI467-I475. 
42. Ducret T, Boudina S, Sorin B, Vacher AM, Gourdou I, Liguoro D, Guerin J, Bresson-Bepoldin L, Vacher P: Effects of prolactin on intracellular calcium concentration and cell proliferation in human glioma cells. Glia 2002, 38:200-2।4.

43. Alpini G, Lenzi R, Sarkozi L, Tavoloni N: Biliary physiology in rats with bile ductular cell hyperplasia. Evidence for a secretory function of proliferated bile ductules. J Clin Invest 1988, 8I:569-578.

44. Mason-Garcia M, Harlan RE, Mallia C, Jeter JRJ, Steinberg HB, Fermin C, Beckman BS: Interleukin-3 or erythropoietin induced nuclear localization of protein kinase $C$ beta isoforms in hematopoietic target cells. Cell Prolif |995, 28: | 45-I 55.

45. Acevedo-Duncan M, Patel R, Whelan S, Bicaku E: Human glioma PKC-iota and PKC-betall phosphorylate cyclin-dependent kinase activating kinase during the cell cycle. Cell Prolif 2002, 35:23-36.

46. Batlle E, Verdù J, Dominguez D, del Mont Liosas M, Diaz V, Loukili N, Paciucci R, Alameda F, Garcia de Herreros A: Protein kinase Calpha activity inversely modulates invasion and growth of intestinal cells. J Biol Chem 1998, 273:I509|-I5098.

47. Sorin B, Vacher AM, Djiane J, Vacher P: Role of protein kinases in the prolactin-induced intracellular calcium rise in Chinese hamster ovary cells expressing the prolactin receptor. I Neuroendocrinol 2000, I 2:910-9|8.

48. Marzioni M, Glaser S, Francis H, LeSage G, Marucci L, Benedetti A, Alvaro D, Taffetani S, Ueno Y, Roskams T, et al:: Autocrine/paracrine regulation of the growth of the biliary tree by the neuroendocrine hormone serotonin. Gastroenterology 2005, 128:121-137.

49. Kelman Z: PCNA: structure, functions, and interactions. Oncogene 1997, 14:629-640.

50. Takada T, Yamamoto T, Koike K, Kanda Y, Miyake A, Sugihara A, Tsujimura $T$, Terada $N$ : Effects of prolactin and estrogen on cell proliferation of the mouse liver induced by partial hepatectomy. In Vivo 1997, I I:409-4I3.

51. Demaria JE, Nagy GM, Freeman ME: Immunoneutralization of prolactin prevents stimulatory feedback of prolactin on hypothalamic neuroendocrine dopaminergic neurons. Endocrine 2000, 12:333-337.

52. Ishii M, Vroman B, LaRusso NF: Isolation and morphologic characterization of bile duct epithelial cells from normal rat liver. Gastroenterology 1989, 97: 1236-1247.

53. LeSage G, Alvaro D, Benedetti A, Glaser S, Marucci L, Baiocchi L, Eisel W, Caligiuri A, Phinizy JL, Rodgers R, et al.: Cholinergic system modulates growth, apoptosis, and secretion of cholangiocytes from bile duct-ligated rats. Gastroenterology 1999, II7:191-199.

54. Fort P, Marty L, Piechaczyk M, el Sabrouty S, Dani C, Jeanteur P, Blanchard JM: Various rat adult tissues express only one major mRNA species from the glyceraldehyde-3-phosphate-dehydrogenase multigenic family. Nucleic Acids Res 1985, 13:1431-1342.

55. Francis H, Franchitto A, Ueno $Y$, Glaser S, Demorrow S, Venter J, Gaudio E, Alvaro D, Fava G, Marzioni M, et al:: H3 histamine receptor agonist inhibits biliary growth of BDL rats by downregulation of the CAMP-dependent PKA/ERKI/2/ELK-I pathway. Lab Invest 2007, 87:473-487.

56. Kato A, Gores GJ, LaRusso NF: Secretin stimulates exocytosis in isolated bile duct epithelial cells by a cyclic AMP-mediated mechanism. J Biol Chem 1992, 267:15523-15529.

57. Kassack M, Hofgen B, Lehmann J, Eckstein N, Quillan J, Sadee W: Functional screening of $G$ protein-coupled receptors by measuring intracellular calcium with a fluorescence microplate reader. J Biomol Screening 2002, 7:233-246.
Publish with Bio Med Central and every scientist can read your work free of charge

"BioMed Central will be the most significant development for disseminating the results of biomedical research in our lifetime. "

Sir Paul Nurse, Cancer Research UK

Your research papers will be:

- available free of charge to the entire biomedical community

- peer reviewed and published immediately upon acceptance

- cited in PubMed and archived on PubMed Central

- yours - you keep the copyright

Submit your manuscript here:

http://www.biomedcentral.com/info/publishing_adv.asp
BioMedcentral 